\title{
Búcsú Szabó Katalintól
}

„Az idő, amit a rózsádra vesztegettél: az teszi olyan fontossá a rózsádat.”

(Antoine de Saint-Exupéry)

E lap hasábjain nem kell magyaráznom, hogy Szabó Katalin, akinek a neve az elmúlt évtizedekben összeforrt a Közgazdasági Szemlével és a Közgázzal is, meghatározó személyisége volt a magyar közgazdaság-tudományi életnek. Maradandót alkotott elméleti közgazdászként, oktatóként és tudományszervezőként is. Életműve robusztus: 15 könyvet írt, amelyek közül a legtöbb vagy alapmüvé vált a maga tudományterületén, vagy mind a mai napig ,a tankönyv” a piacon: mint az Összehasonlító gazdaságtan vagy a Kommunikáció felsőfokon címü művei. Több mint száz folyóiratcikket jegyzett, és műveire közel 1300 hivatkozás érkezett. Felsorolni is nehéz azon témákat, amelyekben alkotott: összehasonlító gazdaságtan, vállalat-gazdaságtan, intézményi gazdaságtan, információ-gazdaságtan, innováció-gazdaságtan. Mi fogta még is össze életmüvét? Meglátásom szerint három dolog.

Az első, hogy mindig a következö időszak legforróbb témáit találta meg, amelyeket nemcsak elméletben, de legtöbbször empirikusan is körbejárt. Mindig ámulatba ejtett kutatói elhivatottsága, a kíváncsisága és nyitottsága a legfrissebb - a legtöbbünk által észre sem vett - újdonságok iránt. Mintha látta volna a jövő kontúrjait, de öt annak részletei érdekelték. Izgatta, hogy miként fog változni gazdaságunk működése, és ennek mi lesz a hatása a társadalmunk fejlődésére. Ez a kíváncsiság, nyitottság jellemezte fiatalabb korában írt műveit, de ugyanez igaz idősebb kori műveire is. Nyitottsága a tudomány iránti alázattal és szorgalommal párosult, elnyühetetlen volt, ha kutatómunkáról volt szó.

A második jellemző, amely meghatározta tudományos pályáját, hogy szeretett csapatban dolgozni. Hazánkban még mindig sok a „magányos farkas” a kutatók között. Ö azonban az együttműködésben hitt minden területen, és bár vezéregyéniség volt, a szó legszebb értelmében, mégis szelíden, kedvesen és töretlen bizalommal fordult munkatársaihoz. Ragaszkodtak is hozzá a fiatal kutatók, és ő ezt a ragaszkodást meg is hálálta: számos müvet írt fiatalokkal együtt, ezzel tanítva őket 
a hivatására. Tudományos munkássága és oktatói munkássága ezért is szétválaszthatatlan, a kettő összeforrt, egymást erősítette. Közhely, de igaz, hogy az együttmüködés sokszor nehezebb, mint önállóan dolgozni, de Szabó Katalin örömmel fektetett be energiát a közös szellemi munkába, és szeretetteljesen támogatta a csapata tagjait. Minden szavából és tettéből a kedvesség és a szeretet sugárzott. Egyik legfontosabb szerzőtársa - férje, Hámori Balázs mellett - Kocsis Éva volt, akivel számos meghatározó könyvet írt, így a Technológiai korszakhatáron. Rugalmas technológiák - regionális hálózatok címüt, amelyet 1997-ben publikáltak, vagy a Digitális paradicsom vagy falanszter: a személyes tömegtermelés címüt, amely 2002-ben jelent meg. Mindig egyenrangúnak tekintette partnereit, bízott bennük, és megtalálta mindenkiben a sokszor rejtett tehetséget, amelyet csak ő volt képes felfedezni. Itt is megvolt a kapcsolat a tudós és az oktató között: felfedező volt a tudományban és a tehetségek felkutatásában is. A közös szellemi munka pótolhatatlan élvezetet okozott neki, és ennek élvezetét átadta kollégáinak is. Magam is azért maradtam a tanszékünkön, mert a belőle áradó emberszeretet baráti és inspiráló közeget teremtett, amelyben az ember kiteljesedhetett, és megtalálhatta a boldogságát. Emlékszem, milyen különleges érzés volt részt venni az Összehasonlító gazdaságtan tankönyv fejezeteinek vitáin Mátraházán, amikor láthattam, hogy Szabó Katalin milyen szeretettel tartja össze a szerzőgárdát, ahogy közöttünk ül, és fogja Hámori Balázs kezét. Az az igazság, hogy még hetvenéves éveiben is a legfiatalabb, legnyitottabb és legvállalkozóbb személyisége volt a közösségnek, amelyhez tartozott, példaképe azoknak, akik ismerték.

A harmadik, hogy minden művét áthatotta az az egyedülálló stílus, amely jellemezte. Ezer müből is könnyedén ki lehetett választani azt, amit ő írt. Müvei nemcsak tudományosak voltak, de szépirodalmiak is. Könyvei letehetetlenek, példái magával ragadók, idézetei ütősek voltak. Minden mindig a helyén volt. Nem véltetlen, hogy az ország majd minden egyetemén az ő müvéből tanítják, hogy miként kell tudományos müvet írni, hiszen ebben (is) utolérhetetlen volt. Egyik fontos üzenete, amit tanítványainak átadott, hogy ne csak tudományos cikkeket olvassunk, hanem szépirodalmat is. Csak így érthetjük meg a társadalmat, amelyben élünk, és amelyet kutatunk. Müveit áttekintve mondhatjuk, hogy Bertolt Brecht müveit valószínüleg nem ismerte senki sem jobban Szabó Katalinnál.

Oktatói pályafutását 1966-ban kezdte a Közgázon, és haláláig ott tanított. Mindenkit ismert, és mindenki ismerte és szerette. Rá valóban igaz, hogy közgazdászok generációit oktatta és nevelte. A poroszos oktatási mód távol állt tőle: minden hallgatójában az egyenrangú felet, az okos és tiszteletre méltó embert látta. Jóindulattal és szeretettel fordult mindenkihez. Nem általánosított, minden hallgatóját önálló személyiségként kezelte. Akkor is, amikor a tömegoktatás miatt ez már elképesztő energiabefektetésbe került. Nem volt hajlandó tömegképzést nyújtani. Ha kellett, éjjel-nappal dolgozott, de minden tanulmányt, dolgozatot elolvasott, és részletesen visszajelzett a hallgatóinak.

Magam is egy vagyok a Szabó Katalin-tanítványok közül, elsőéves hallgatóként jártam hozzá diploma-proszemináriumra, amikor a beadandóm alapján demonstrátornak hívott, és a beadandómat közöltette a Magyar Tudomány címü 
folyóiratban. Valljuk meg, nem sok oktató gondolkodik el azon, hogy egy elsőéves hallgatójának írását publikálni kellene, és ebbe hajlandó időt és energiát fektetni. Utána 18 évig dolgozhattunk együtt.

Szabó Katalin halála pótolhatatlan veszteség a Közgazdasági Szemle szerkesztőségének, olvasóinak és a teljes magyar közgazdász-társadalomnak. Mégsem az elmúlás feletti fájdalmammal és szomorúságommal szeretném zárni írásomat, hanem azzal az üzenettel - talán hozzá is eljut -, hogy gondolatai, szemléletmódja, világlátása, emberszeretete és a hivatása iránti elhivatottsága tovább él bennünk, azokban, akik szerettük és tiszteltük.

Rosta Miklós tanszékvezető egyetemi docens, BCE 